\title{
Exploring on Measures in Improving Citizens' Environmental Participation in Higher Education in China
}

\author{
Xu Binbin ${ }^{1,2 *}$, Ms.Ma.Glena Mendoza ${ }^{1}$ \\ ${ }^{1}$ College of Teacher Education, University of the Cordilleras, Baguio City, Philippines \\ ${ }^{2}$ College of Music, Linyi University, Linyi City, China. \\ *Corresponding author.Email:Xubinbin@lyu.edu.cn
}

\begin{abstract}
Chinese legislation has begun to promote environmental education in schools. Now, citizens generally have environmental awareness and environmental knowledge. However, citizens are currently very low in active participation in environmental protection activities.

We hope to exploring how to improving citizens'environmental participation in Higher Education in China. Try to find out why citizens are not actively involved in environmental protection activities. After finding out the reasons, combined with the social background, analyze how they were formed, and finally determine the direction to solve the problem.

Two research methods are used. One is to consult the literature, mainly to understand the social background, laws and regulations; The second is to use interviews and questionnaire surveys, with 200 respondents, including ordinary residents, college students, and government workers. Questions include environmental protection knowledge, enthusiasm for environmental protection activities, reasons for not actively participating in public environmental protection activities, and whether they understand relevant policies.

Through research, we found that more than $90 \%$ of citizens understand basic environmental protection knowledge and have the habit of saving water and electricity. However, there is about $12.1 \%$ had participation in public environmental protection activities, mainly because they do not understand the policies and have no channels for participation.

Universities can open courses on environmental protection policies and laws to let students learn about public environmental protection activities and seminars; they can use community services to promote public environmental protection activities; relevant professional teachers should actively participate in the government's construction environment evaluation. As an advanced stage of education, universities should give better play to education and guidance so that the society can raise awareness of participation in environmental protection activities.
\end{abstract}

Keywords: Environment, Education, Citizen's Participation, University, Improve.

\section{INTRODUCTION}

In the 20th century, human society has achieved unprecedented rapid development. At the same time, our natural environment has entered a cycle of rapid deterioration. China has paid more and more attention to environmental protection. General Secretary Xi Jinping put forward the concept that "green water and green mountains are golden mountains and silver mountains", and the concept of environmental protection has been deeply rooted in the hearts of the people, and it seems that the era of environmental protection has come However, I really want to ask how others participate in environmental protection. Most of them just think that they don't litter, clean their surroundings, use less plastic bags, plant trees, etc. It should be said that this is just the most basic way to participate.

However, China has a vast territory and a large population, and its environmental problems are relatively serious. If there is no large-scale public participation and the improvement of national environmental awareness, the environmental situation 
will not be able to match people's requirements for a higher quality of life and the increasing global environmental protection. The waves keep pace. The extensiveness, complexity and arduousness of my country's environmental problems determine that environmental protection is a long-term national undertaking. Therefore, we must carefully study the important role of public participation, the status quo of public participation, explore ways to improve citizens' participation in environmental protection, and create a new situation in which all citizens participate in environmental protection. [1]

\section{OBJECTIVES}

Citizen participation in environmental protection is very important to the country. Citizen participation can help the government formulate more reasonable policies, make environmental decision-making more scientific and democratic, effectively maintain environmental order, and make policy implementation faster and achieve better results. [2] Citizens can also share the pressure of government work through environmental supervision, promptly discover deficiencies in environmental protection policies and laws and regulations, and reduce the cost of environmental policy adjustments. [3]

Therefore, we hope to find out why citizens do not actively participate in environmental protection activities. After finding out the reasons, combined with the social background, analyze their formation methods, and finally determine the direction to solve the problem.

\section{METHODOLOGY}

We conducted a survey of 215 citizens, including farmers, college students, urban white-collar workers, the elderly and government workers. The survey questions include whether you have participated in environmental protection activities, your understanding of environmental protection activities, what good environmental protection habits you have, and the relationship between citizen participation and government leadership. In addition, by consulting data, we understand the changes in China's environmental education, environmental protection policies and citizens' awareness of environmental protection in the past two decades, and compare them with the results of our investigations to find out the current situation of citizens' participation in environmental protection, existing problems and The reason for formation.

\section{RESULTS}

After surveying 215 people and consulting data, it was found that since 2010, the public's awareness of environmental protection in my country has increased significantly. In some large cities, many citizens have organized and actively participated in environmental protection actions, which means that the strength of individual citizens began to participate in environmental protection. More than $90 \%$ of citizens believe that they have rights and obligations in environmental protection. While paying attention to their words and deeds, they have begun to interfere with or report some environmental damage. This shows the importance of citizen participation in the field of environmental protection. Sex is getting deeper and deeper understanding.

The "People's Livelihood Index" guided by the State Environmental Protection Administration in my country shows that the public's awareness of environmental protection in my country has reached $85.4 \%$, and $27.1 \%$ of the public expressed their "most concern" about environmental pollution. The public's attention to environmental protection shows that China's environmental protection development is facing an opportunity to "call a hundred responses". The public's enthusiasm for participating in environmental protection is very high. The relevant government departments attach great importance to it and have made certain achievements. However, public participation in environmental protection in my country is not optimistic. Compared with other developed countries in the world, it is still relatively backward and still has many shortcomings. The problems need to be solved urgently, mainly in:

First, the general public's cultural quality and environmental awareness are still relatively low. The survey shows that only $6.3 \%$ of the public actively participate in environmental protection. The public's current environmental awareness is still at a low level, mainly because of concerns that the environment will affect life and health, and lack of active environmental protection awareness.

Government surveys show that the environmental morality of urban residents is higher than that of rural residents; citizens have a strong "government-dependent" type of environmental awareness. Everyone wants a good environment, but does not know how to participate in environmental protection. [4] On the whole, the overall level of citizens' environmental protection awareness is low, which directly leads to the low degree of public participation in environmental protection activities.

Second, they have little knowledge of environmental protection laws.After investigation, $63.5 \%$ of citizens are not aware of environmental protection laws, and they only feel that the violation of citizens' environmental rights is incorrect, [5] and they do not know that this is illegal. Citizens are accustomed to turning to the government for help instead of defending their rights through legal means. 
Third, the current public participation in my country is basically end-participation (participation after environmental pollution and ecological damage occurs, that is, end-participation). This mode of participation is actually a remedy, it is too late. The damage and pollution have already been caused. Remedial measures can be taken at this time. Although it can prevent future disasters, it cannot recover the losses caused. The best way for citizens to participate in protecting the environment is to put forward opinions before sabotage activities to prevent such activities from happening. [6]

Fourth, the main form of public participation still belongs to participation under the initiative of the government. When the government decides to implement a certain environmental protection policy, citizens will be organized to participate; once the government does not implement the policy, citizens lack the desire to actively participate and express their opinions.

\section{DISCUSSION}

What should universities do to promote citizen participation in environmental protection? Universities have the highest academic influence in society. There are professors with professional knowledge and a large number of students as volunteers. Therefore, universities can use social influence to actively participate in the promotion of environmental protection awareness and the popularization of laws.

\subsection{Improve environmental protection awareness}

Strengthen the publicity and education of environmental protection, so that the public can realize the current environmental crisis, so that people can realize the importance of environmental protection, and raise the public's sense of responsibility. Universities should use their knowledge advantages to popularize environmental protection knowledge, so that the public's enthusiasm for participating in environmental protection will be improved, and they must realize that "environmental protection requires the joint action of the whole society." [2] The university should cooperate with the government to educate the public on environmental protection through a large number of practical cases through community services and web lectures.

\subsection{Help citizens understand environmental protection laws}

At present, China's environmental protection laws have clarified the public's right to know, supervise and participate. Only $42 \%$ of citizens know the specific content of the law, the rights and duties of citizens.
Universities should start environmental law courses to let students understand the law. Then spread to citizens through students. Volunteers should also be organized to promote in enterprises and communities to help citizens understand environmental protection laws.

\subsection{Carry out diversified environmental protection activities and broaden environmental protection channels}

At present, there are relatively few forms of citizen participation in environmental protection activities in my country. The environmental protection activities organized by the government have the greatest impact. The environmental protection activities organized by social groups and individuals have little impact and have a relatively small impact. Therefore, universities should help various environmental protection associations, encourage professors and students to actively participate in environmental protection association activities, take advantage of professional knowledge, organize various environmental protection activities, such as theme lectures, simulation experiments, etc., so that citizens have more opportunities and space to participate Environmental protection.

\section{CONCLUSION}

Citizens' low participation in environmental protection activities is due to their insufficient environmental awareness and lack of understanding of the law. Universities have a high social influence and should take the initiative to assume social responsibilities, give full play to the functions of education and academic guidance, use education to enhance students' awareness of environmental participation and understanding of environmental protection laws, and actively participate in community services and knowledge publicity to enhance citizens' environmental participation And understanding of environmental protection laws. Citizens are more involved in environmental protection activities and government environmental decision-making in order to better protect the environment and realize the harmonious development of people and the earth.

\section{REFERENCES}

[1] K. Huang, Research on the Theory and Practice of Public Participation in Environmental Protection[J].People's Forum,2015(4):35-37.

[2] W. Liu, Analysis of the public participation system in my country's environmental protection[J].Science and Technology Getting Rich Guide, 2015(02).

[3] F.S. Lin, Public Participation in Environmental Protection[J].Fujian Environment, 2000, 1:6-7. 
[4] W.M. Xu, On Improving Public Participation in Environmental Protection in my country[J].Journal of Shandong University, 1999, 2: 98-100.

[5] G.P. Qu, Public Participation and Social Regulation in Environmental Protection, [EB/OL] DOI: http://www.66wen.com/06gx/shuili/shuiwen/20061 028/47653.html,2006-10-28

[6] H.Y. Guo, Current Status, Problems and Countermeasures of Public Participation in Environmental Protection inChina,[EB/OL] Unity2018, 5.DOI:http://www.minge.gov.cn/n1/20 19/0304/c422442-30956531.html 